\title{
Faktor-Faktor yang Mempengaruhi Pengambilan Keputusan Petani dalam Penggunaan Asuransi Usahatani Padi (AUTP) di Kecamatan Selogiri Kabupaten Wonogiri
}

\author{
Lusi Hikmawati ${ }^{1 *}$, Sugihardjo ${ }^{2}$, Putri Permatasari \\ ${ }^{1}$ Prodi Penyuluhan dan Komunikasi Pertanian, Fakultas Pertanian, Universitas Sebelas Maret \\ ${ }^{2}$ Departemen Sosial dan Ekonomi Pertanian, Fakultas Pertanian, Universitas Sebelas Maret \\ Email: hikmawatilusi@gmail.com, sugihardjo@staff.uns.ac.id, putripermatasari@staff.uns.ac.id
}

\begin{abstract}
Penelitian ini bertujuan untuk mengkaji faktor-faktor yang mempengaruhi pengambilan keputusan petani, tingkat pengambilan keputusan petani, dan pengaruh antara faktor-faktor yang mempengaruhi pengambilan keputusan terhadap pengambilan keputusan petani dalam penggunaan Asuransi Usahatani Padi (AUTP) di Kecamatan Selogiri, Kabupaten Wonogiri. Penelitian ini menggunakan metode penelitian kuantitatif dengan teknik survei. Pengambilan sampel dilakukan dengan metode proportional random sampling dengan jumlah sampel sebanyak 70 petani. Analisis data menggunakan regresi linier berganda. Hasil penelitian menunjukkan bahwa faktor pendidikan, pendapatan, luas lahan, pengalaman usahatani, tingkat pengambilan risiko, tingkat keaktifan penyuluh, dan kemudahan penggunaan secara serentak mempengaruhi pengambilan keputusan petani penggunaan Asuransi Usahatani Padi (AUTP). Faktor-faktor yang mempengaruhi pengambilan keputusan secara parsial yang berpengaruh signifikan yaitu pendidikan, pengalaman usahatani, tingkat pengambilan risiko, dan tingkat keaktifan penyuluh, sedangkan yang tidak berpengaruh signifikan yaitu pendapatan, luas lahan, dan kemudahan penggunaan.
\end{abstract}

Keywords : Asuransi Usahatani Padi (AUTP); Pengambilan Keputusan; Petani

\section{Pendahuluan}

Petani berperan sebagai pelaku utama dalam sektor pertanian yang berorientasi pada pemenuhan kebutuhan pangan bagi masyarakat. Peranan petani sangat penting dalam sektor pertanian maka perlu ditingkatkan kesejahteraan petani untuk mendukung keberlanjutan usahatani. Namun, petani menghadapi permasalahan dalam mengelola usahatani terutama pada risiko ketidakpastian yang sulit untuk diprediksi. Menurut (Mustika et al., 2019), risiko ketidakpastian dalam usahatani berupa kekeringan, banjir, maupun serangan hama dan penyakit yang dapat mengakibatkan gagal panen. Kerugian akibat gagal panen menimbulkan keresahan petani sehingga petani kurang sejahtera.

Salah satu upaya pemerintah untuk melindungi petani dalam menghadapi risiko ketidakpastian yaitu penggunaan Asuransi Usahatani Padi (AUTP) yang sudah dilaksanakan sejak tahun 2015. Asuransi Usahatani Padi (AUTP) telah diatur dalam Peraturan Menteri Pertanian Nomor 40/Permentan/SR.230/7/2015 mengenai Fasilitasi Asuransi Pertanian. Petani akan memperoleh ganti rugi apabila mengalami gagal panen sesuai dengan syarat pengajuan klaim Asuransi Usahatani Padi (AUTP).

Kecamatan Selogiri menjadi daerah sentra tanaman padi di Kabupaten Wonogiri dengan produktivitas padi tertinggi. Menurut data Badan Pusat Statistik Kabupaten Wonogiri tahun 2019 bahwa produktivitas padi di Kecamatan Selogiri sebesar 6,13 ton/ha, sedangkan produktivitas padi di kecamatan lainnya berkisar 4-5 ton/ha. Masalah yang sering dihadapi petani meskipun telah mencapai produktivitas padi yang tinggi di Kecamatan Selogiri yaitu serangan Organisme Pengganggu Tanaman
(OPT) dan kekeringan cukup tinggi. Asuransi Usahatani Padi (AUTP) memiliki manfaat penting sebagai solusi kegagalan panen, maka Asuransi Usahatani Padi terus dilaksanakan. Salah satunya dilaksanakan di Kecamatan Selogiri.

Permasalahan yang terjadi yaitu petani di Kecamatan Selogiri belum banyak yang menggunakan Asuransi Usahatani Padi (AUTP). Sebagian petani masih belum percaya terhadap besarnya manfaat Asuransi Usahatani Padi (AUTP). Kepercayaan petani untuk menggunakan Asuransi Usahatani Padi (AUTP) tentu didasarkan pada pengambilan keputusan petani yang dipengaruhi oleh beberapa faktor dan melalui beberapa tahapan. Berdasarkan hal tersebut, maka sangat penting untuk dilakukan penelitian mengenai "Faktor-Faktor yang Mempengaruhi Pengambilan Keputusan Petani dalam Penggunaan Asuransi Usahatani Padi (AUTP) di Kecamatan Selogiri, Kabupaten Wonogiri”.

\section{Metodologi}

Penelitian dilakukan di Kecamatan Selogiri, Kabupaten Wonogiri. Metode penentuan lokasi penelitian dilakukan secara sengaja (purposive) karena Kecamatan Selogiri menjadi salah satu kecamatan di Kabupaten Wonogiri dengan luas lahan usahatani padi yang diasuransikan tertinggi yaitu 115 Ha pada tahun 2020 . Populasi pada penelitian ini berjumlah 280 petani. Pengambilan sampel menggunakan metode proportional random sampling. Jumlah sampel pada penelitian ini sebanyak 70 petani. Jenis data yang digunakan yaitu data primer dan sekunder. Teknik pengumpulan data menggunakan kuisioner, wawancara, pencatatan, dan dokumentasi. Analisis data menggunakan uji regresi linier 
berganda. Persyaratan untuk dapat dilakukan uji regresi linier berganda maka dilakukan uji asumsi klasik terlebih dahulu. Pengujian hipotesis terdiri dari uji secara simultan (uji F), koefisien determinasi, dan uji secara parsial (uji t). Persamaan regresi linier berganda dapat dirumuskan sebagai berikut (Riyanto dan Aglis, 2020):

$Y=a+b_{1} X_{1}+b_{2} X_{2}+b_{3} X_{3}+\ldots+b_{i} X_{i+} \varepsilon$

Keterangan:

$\mathrm{Y}=$ Pengambilan Keputusan Petani dalam Penggunaan AUTP

$\mathrm{X}_{1}=$ Pendidikan

$\mathrm{X}_{2}=$ Pendapatan

$\mathrm{X}_{3}=$ Luas Lahan

$\mathrm{X}_{4}=$ Pengalaman Usahatani

$\mathrm{X}_{5}=$ Tingkat Pengambilan Risiko

$\mathrm{X}_{6}=$ Tingkat Keaktifan Penyuluh

$\mathrm{X}_{7}=$ Kemudahan Penggunaan

$\mathrm{a}=$ Konstanta

$\mathrm{b}=$ Koefisien regresi

3. Hasil

3.1. Faktor-Faktor yang Mempengaruhi Pengambilan Keputusan Petani dalam Penggunaan Asuransi Usahatani Padi (AUTP)

\subsubsection{Pendidikan}

Pendidikan yang ditempuh petani pada penelitian ini dikategorikan menjadi pendidikan formal dan non formal. Berdasarkan hasil analisis menunjukkan bahwa sebagian besar responden termasuk dalam kategori cukup tinggi sebanyak 37 orang $(52,85 \%)$. Responden ini memiliki tingkat pendidikan formal rata-rata tamat SMP dan tingkat pendidikan non formal rata-rata mengikuti kegiatan penyuluhan 3-4 kali.

\subsubsection{Pendapatan}

Pendapatan dalam penelitian ini yaitu keseluruhan pendapatan yang diperoleh responden baik dalam usahatani maupun di luar usahatani. Berdasarkan hasil analisis menunjukkan bahwa sebagian besar responden memiliki pendapatan per bulan dengan kategori rendah berkisar Rp 1.100.000,00 hingga Rp 2.000.000,00 sejumlah 25 orang $(35,70 \%)$. Responden pada kategori ini yaitu petani yang memperoleh pendapatan berasal dari usahatani dan ternak.

\subsubsection{Luas Lahan}

Luas lahan pada penelitian ini yaitu luas lahan yang digunakan petani untuk melakukan usahataninya baik lahan milik sendiri, sewa, maupun penggarap. Berdasarkan hasil analisis bahwa luas lahan reponden yang mengikuti Asuransi Usahatani Padi (AUTP) paling banyak berada pada kategori rendah yaitu $0,26 \mathrm{Ha}-0,50 \mathrm{Ha}$ sejumlah 30 orang atau $42,85 \%$. Hal itu dikarenakan modal yang dimiliki petani terbatas.

\subsubsection{Pengalaman Usahatani}

Pengalaman usahatani pada penelitian ini merupakan lamanya responden dalam melakukan usahatani. Berdasarkan hasil analisis bahwa sebagian besar pengalaman responden dalam mengelola usahatani padi termasuk dalam kategori sangat tinggi yaitu dengan kurun waktu lebih dari 20 tahun sejumlah 22 orang atau $31,43 \%$. Responden yang memiliki pengalaman usahatani yang lama sudah mengetahui risiko usahatani yang sering dialaminya sehingga petani mencari solusi jika gagal panen dengan menggunakan program baru berupa Asuransi Usahatani Padi (AUTP).

\subsubsection{Tingkat Pengambilan Risiko}

Pengambilan keputusan petani untuk kepentingan usahatani didasarkan pada tingkat risiko yang akan ditanggung oleh petani. Berdasarkan hasil analisis bahwa pengambilan risiko usahatani oleh petani responden paling banyak pada kategori cukup tinggi sejumlah 27 orang atau $38,58 \%$. Responden pada kategori cukup tinggi yaitu petani yang menghadapi dua jenis risiko usahatani berupa kekeringan dan hama penyakit sebesar $<75 \%$ dari luas lahan yang diusahakan petani responden. Risiko usahatani berupa kekeringan dan hama penyakit tersebut dapat dijadikan alasan petani responden mau untuk mengikuti Asuransi Usahatani Padi (AUTP) sebagai solusi gagal panen.

\subsubsection{Tingkat Keaktifan Penyuluh}

Tingkat keaktifan penyuluh pada penelitian ini yaitu frekuensi penyuluh dalam melakukan kegiatan penyuluhan. Sejumlah 33 responden menilai keaktifan penyuluh di Kecamatan Selogiri termasuk pada kategori tinggi, hal itu dikarenakan frekuensi penyuluh dalam memberikan penyuluhan kepada petani responden sebanyak 4 kali bersamaan dengan pertemuan kelompok tani setiap 35 hari. Penyuluh aktif dalam memberikan rekomendasi kepada petani untuk menggunakan AUTP sebagai salah satu solusi gagal panen. Penyuluh berperan dalam mendampingi petani pada proses pendaftaran hingga proses klaim AUTP.

\subsubsection{Kemudahan Penggunaan}

Kemudahan penggunaan Asuransi Usahatani Padi (AUTP) pada penelitian ini yaitu kemudahan dalam proses pendaftaran, pembayaran premi, penerimaan polis, dan proses klaim. Berdasarkan hasil analisis bahwa paling banyak responden sejumlah 36 orang atau $51,43 \%$ menyatakan cukup mudah dalam penggunaan Asuransi Usahatani Padi (AUTP). Proses pendaftaran dan penerimaan polis mudah, sedangkan proses klaim dianggap kurang mudah karena mayoritas petani responden belum mendapatkan klaim karena intensitas kerusakan yang dialami oleh petani biasanya kurang dari $75 \%$ sehingga syarat untuk memperoleh klaim menjadi tidak terpenuhi.

\subsection{Pengambilan Keputusan Petani dalam Penggunaan} Asuransi Usahatani Padi (AUTP)

Pengambilan keputusan petani dalam menggunakan Asuransi Usaha Tani Padi (AUTP) dilakukan melalui beberapa tahapan. Tahap yang dilakukan yaitu tahap pengenalan, tahap persuasif, tahap keputusan, dan tahap konfirmasi. Hal tersebut dapat diketahui tingkat pengambilan keputusan petani dalam penggunaan Asuransi Usahatani Padi (AUTP).

\subsubsection{Tahap Pengenalan}

Tahap pengenalan merupakan tahapan awal ketika petani mengetahui adanya penggunaan Asuransi Usahatani Padi (AUTP) sebagai solusi gagal panen. Berdasarkan hasil analisis menunjukkan bahwa sebagian responden mengetahui Asuransi Usahatani Padi (AUTP) pada kategori cukup tinggi sejumlah 31 orang (44,29\%). Petani mengetahui informasi mengenai Asuransi Usahatani Padi (AUTP) berasal dari penyuluh melalui kegiatan penyuluhan khususnya saat memasuki tanam padi. Materi penyuluhan 
Asuransi Usahatani Padi (AUTP) diantaranya manfaat, syarat dan proses pendaftaran serta proses klaim Asuransi Usahatani Padi (AUTP).

\subsubsection{Tahap persuasif}

Tahap persuasif merupakan tahap saat sikap petani untuk berkenan atau tidak berkenan terhadap Asuransi Usahatani Padi (AUTP). Tahap persuasif dilihat pada ketertarikan Asuransi Usahatani Padi (AUTP) baik aspek ketertarikan terhadap manfaat, kemudahan syarat pendaftaran, proses pendaftaran, dan proses klaim AUTP. Berdasarkan hasil analisis bahwa ketertarikan sebagian besar petani responden terhadap penggunaan Asuransi Usahatani Padi (AUTP) termasuk kategori tinggi sejumlah 30 orang $(42,86 \%)$. Petani responden tertarik pada manfaat, kemudahan syarat pendaftaran dan proses pendaftaran. Petani responden berusaha mencari informasi setelah mengetahui adanya AUTP berasal dari penyuluh dan petani lainnya.

\subsubsection{Tahap Keputusan}

Tahap keputusan pada penelitian ini dilihat dari tingkat keyakinan petani dapat mengambil keputusan untuk menggunakan Asuransi Usahatani Padi (AUTP), karena responden penelitian sudah ditentukan yang menggunakan AUTP. Berdasarkan hasil analisis bahwa sebagian besar responden pada tahap keputusan dalam menggunakan Asuransi Usahatani Padi (AUTP) berada pada kategori tinggi sejumlah 26 responden atau 37,14\%. Petani yakin menggunakan Asuransi Usahatani Padi (AUTP) karena mereka waspada jika terjadi gagal panen. Petani juga memperoleh informasi secara individu dari petani lainnya yang sudah pernah memperoleh ganti rugi atas kerusakan tanaman sehingga petani mengambil keputusan untuk menggunakan Asuransi Usahatani Padi (AUTP).

\subsubsection{Tahap Konfirmasi}

Tahap konfirmasi pada penelitian ini yaitu usaha petani dalam mencari informasi untuk menguatkan keputusannya. Tahap ini juga dilihat kesediaan petani untuk melanjutkan Asuransi Usahatani Padi (AUTP) pada masa tanam berikutnya. Berdasarkan hasil analisis bahwa sebagian besar responden pada tahap konfirmasi termasuk kategori tinggi sejumlah 30 orang atau $42,86 \%$. Petani responden melakukan pencarian informasi sebagai penguat keputusannya berasal dari penyuluh, petani lainnya, dan koran. Kesediaan petani untuk menggunakan Asuransi Usahatani Padi (AUTP) pada masa tanam berikutnya yaitu mereka menggunakan AUTP dengan luas lahan tetap karena mereka waspada jika gagal panen dan sudah merasa lebih baik dengan besarnya ganti rugi yang sudah ditetapkan daripada tidak mendapatkan ganti rugi sama sekali.

\subsection{Pengaruh Faktor-Faktor yang Mempengaruhi \\ Pengambilan Keputusan terhadap Pengambilan \\ Keputusan Petani dalam Penggunaan Asuransi Usahatani Padi (AUTP)}

Faktor-faktor yang mempengaruhi pengambilan keputusan petani dalam penggunaan Asuransi Usaha Tani Padi (AUTP) menggunakan analisis regresi linier berganda. Penelitian ini dilakukan uji asumsi klasik sebagai syarat dilakukannya analisis regresi linier berganda. Uji asumsi klasik digunakan sebagai syarat dalam penggunaan model regresi linier berganda. Uji asumsi klasik pada penelitian ini yaitu uji normalitas, uji multikolinearitas, dan uji heterokedastisitas. Uji normalitas merupakan uji yang digunakan untuk mengetahui model regresi variabel pengganggu atau residual memiliki distribusi normal atau tidak normal. Uji normalitas yang digunakan pada penelitian ini yaitu uji Kolmogorov-Smirnov dengan nilai signifikansi 0,137 yang lebih besar dari taraf signifikansi 0,05. Nilai tersebut dapat diasumsikan bahwa model regresi berdistribusi normal. Uji multikolinearitas merupakan uji yang digunakan untuk mengetahui model regresi ditemukan ada tidaknya korelasi antar variabel bebas. Hasil perhitungan nilai tolerance menunjukkan bahwa masing-masing variabel lebih besar dari 0,1, sedangkan nilai VIF bahwa masingmasing variabel kurang dari 10. Hasil uji menunjukkan bahwa tidak ada korelasi antar variabel independen (tidak mengalami multikolinearitas). Uji hererokedastisitas merupakan uji untuk mengetahui model regresi apakah terjadi ketidaksamaan variansi dari residual atau pengamatan ke pengamatan lainnya. Hasil perhitungan menunjukkan bahwa masing-masing variabel independen memiliki nilai signifikasi lebih dari 0,05 sehingga model regresi tidak terjadi gejala heterokedastisitas.

Tabel 1. Hasil Analisis Regresi Pengaruh Faktor-Faktor yang Mempengaruhi Pengambilan Keputusan terhadap Pengambilan Keputusan Petani dalam Penggunaan Asuransi Usahatani Padi (AUTP)

\begin{tabular}{lcl} 
Model & B & Sig \\
\hline (Constant) & 15,653 & 0,000 \\
Pendidikan & 0,538 & $0,000^{*}$ \\
Pendapatan & 0,501 & 0,245 \\
Luas Lahan & 0,555 & 0,325 \\
Pengalaman Usahatani & 0,520 & $0,000^{*}$ \\
Tingkat Pengambilan Risiko & 1,030 & $0,000^{*}$ \\
Tingkat Keaktifan Penyuluh & 0,440 & $0,033^{*}$ \\
Kemudahan Penggunaan & 0,313 & 0,106 \\
\hline F hitung = 18,623 & & 0,000 \\
R Square = 0,678 & & \\
\hline Sumbr: Analsin Data Primer,
\end{tabular}

Sumber: Analisis Data Primer, (2021)

Berdasarkan analisis regresi linier berganda maka diperoleh persamaan model regresi:

$\mathrm{Y}=15,653+0,538 \mathrm{X}_{1}+0,501 \mathrm{X}_{2}+0,555 \mathrm{X}_{3}+0,520 \mathrm{X}_{4}+$ $1,030 X_{5}+0,440 X_{6}+0,313 X_{7}$

Keterangan :

$\mathrm{Y}=$ Pengambilan Keputusan Petani dalam Penggunaan Asuransi Usaha Tani Padi (AUTP)

$\mathrm{X}_{1}=$ Pendidikan

$\mathrm{X}_{2}=$ Pendapatan

$\mathrm{X}_{3}=$ Luas Lahan

$\mathrm{X}_{4}=$ Pengalaman Usahatani

$\mathrm{X}_{5}=$ Tingkat Pengambilan Risiko

$\mathrm{X}_{6}=$ Tingkat Keaktifan Penyuluh

$\mathrm{X}_{7}=$ Kemudahan Penggunaan

Berdasarkan tabel 1 hasil uji $\mathrm{F}$ menunjukkan bahwa sig $0,00 \leq 0,05$. Berdasarkan hasil tersebut, maka Ho ditolak dan $\mathrm{H}_{1}$ diterima, artinya variabel bebas yaitu faktor pendidikan, pendapatan, luas lahan, pengalaman usahatani, tingkat pengambilan risiko, tingkat keaktifan penyuluh, dan kemudahan penggunaan secara serentak berpengaruh signifikan terhadap variabel terikat yaitu pengambilan 
keputusan petani dalam penggunaan Asuransi Usahatani Padi (AUTP) di Kecamatan Selogiri, Kabupaten Wonogiri. Adapun koefisien determinasi $\left(\mathrm{R}^{2}\right)$ diperoleh sebesar 0,678 artinya faktor pendidikan, pendapatan, luas lahan, pengalaman usahatani, tingkat pengambilan risiko, tingkat keaktifan penyuluh, dan kemudahan penggunaan dapat mempengaruhi pengambilan keputusan petani dalam penggunaan Asuransi Usahatani Padi (AUTP) sebesar $67,8 \%$. Sisa dari nilai koefisien determinasi $\left(\mathrm{R}^{2}\right)$ tersebut sebesar $32,2 \%$ diterangkan oleh faktor-faktor yang tidak diteliti.

Berdasarkan tabel 1 dapat diketahui pula pengaruh masing-masing variabel bebas terhadap variabel terikat yang diperoleh dari hasil uji koefisien regresi secara parsial (uji t) sehingga dapat diuraikan sebagai berikut:

a. Pengaruh Pendidikan terhadap Pengambilan Keputusan

Petani dalam Penggunaan Asuransi Usahatani Padi (AUTP)

Faktor pendidikan memiliki nilai koefisien sebesar 0,538 . Koefisien bernilai positif artinya terjadi hubungan yang positif antara faktor pendidikan dengan pengambilan keputusan sehingga semakin tinggi nilai faktor pendidikan maka semakin tinggi pula pengambilan keputusan petani. Hal ini sejalan dengan kondisi di lapang bahwa faktor pendidikan secara parsial berpengaruh signifikan terhadap pengambilan keputusan petani dalam penggunaan Asuransi Usahatani Padi (AUTP) di Kecamatan Selogiri, Kabupaten Wonogiri. Hal tersebut ditunjukkan bahwa nilai sig. atau $p$ value pada faktor pendidikan $\left(\mathrm{X}_{1}\right)$ sebesar $0,00<0,05$ maka Ho ditolak dan $\mathrm{H}_{1}$ diterima.

Hasil penelitian sesuai dengan (Aprelesia et al., 2019) bahwa variabel pendidikan memiliki pengaruh yang signifikan terhadap keputusan petani untuk mengikuti AUTP. Petani yang menempuh pendidikan lebih tinggi maka petani akan cenderung menerima inovasi teknologi dan memilih mengikuti Pendidikan yang ditempuh petani dalam penelitian ini yaitu pendidikan formal dan pendidikan non formal. Sebagian besar responden memiliki tingkat pendidikan cukup tinggi. Tingkat pendidikan formal sebagian responden tidak terlalu tinggi yaitu tingkat SMP, tetapi mereka juga didukung dengan pendidikan non formal berupa penyuluhan yang disampaikan oleh Petugas Penyuluh Lapang (PPL) di kecamatan. Intensitas petani mengikuti penyuluhan rata-rata 3-4 kali dalam satu tahun terakhir. Petani menerima pengetahuan mengenai AUTP dan memperkirakan manfaat menggunakan atau tidak menggunakan AUTP yang disesuaikan dengan risiko usahatani padi yang dihadapinya. Pendidikan dapat mempengaruhi pola pikir dan keterbukaan terhadap perubahan yang ada sehingga petani lebih cepat dalam mengambil keputusan dalam menggunakan AUTP untuk usahatani yang lebih baik dan menguntungkan.

b. Pengaruh Pendapatan terhadap Pengambilan Keputusan

Petani dalam Penggunaan Asuransi Usahatani Padi (AUTP)

Faktor pendapatan memiliki nilai koefisien sebesar 0,501 . Koefisien bernilai positif artinya terjadi hubungan yang positif antara faktor pendapatan dengan pengambilan keputusan sehingga semakin tinggi nilai faktor pendapatan maka semakin tinggi pula pengambilan keputusan petani.
Hal ini tidak sejalan di kondisi lapang bahwa faktor pendapatan secara parsial tidak berpengaruh signifikan terhadap pengambilan keputusan petani dalam penggunaan Asuransi Usahatani Padi (AUTP) di Kecamatan Selogiri, Kabupaten Wonogiri. Hal tersebut ditunjukkan bahwa nilai sig. atau $p$ value pada faktor pendapatan $\left(\mathrm{X}_{2}\right)$ sebesar 0,245 $>0,05$ maka Ho diterima dan $\mathrm{H}_{1}$ ditolak.

Hasil penelitian ini sesuai dengan pendapat (Wahyuningsih \& Hasan, 2019) bahwa pendapatan tidak berpengaruh signifikan untuk menggunakan Asuransi Usahatani Padi (AUTP). Petani dengan pendapatan yang tinggi maupun rendah untuk mengambil keputusan yang sama dalam menggunakan Asuransi Usahatani Padi (AUTP). Sebagian besar petani responden memiliki pendapatan dalam kategori rendah berkisar Rp.1.100.000,00 hingga Rp 2.000.000,00, tetapi mereka tetap mengambil keputusan untuk menggunakan Asuransi Usahatani Padi (AUTP). Mereka merasa mudah dalam membayar premi atau sejumlah nilai uang yang harus dibayarkan sesuai dengan luas lahan untuk dapat menggunakan Asuransi Usahatani Padi (AUTP) karena sebagian besar pembayaran premi berasal dari kas kelompok tani.

c. Pengaruh Luas Lahan terhadap Pengambilan Keputusan Petani dalam Penggunaan Asuransi Usahatani Padi (AUTP)

Faktor luas lahan memiliki nilai koefisien regresi sebesar 0,555. Koefisien bernilai positif artinya terjadi hubungan yang positif antara faktor luas lahan dengan pengambilan keputusan sehingga semakin tinggi nilai faktor luas lahan maka semakin tinggi pula pengambilan keputusan petani. Hal ini tidak sejalan di kondisi lapang bahwa faktor luas lahan secara parsial tidak berpengaruh signifikan terhadap pengambilan keputusan petani dalam penggunaan Asuransi Usahatani Padi (AUTP) di Kecamatan Selogiri, Kabupaten Wonogiri. Hal tersebut ditunjukkan bahwa nilai sig. atau $p$ value pada faktor luas lahan $\left(\mathrm{X}_{3}\right)$ sebesar $0,325>$ 0,05 maka Ho diterima dan $\mathrm{H}_{1}$ ditolak.

Hasil penelitian sesuai dengan (Syakir, 2016) bahwa luas lahan tidak berpengaruh terhadap keputusan petani dalam keikutsertaan asuransi usahatani padi, karena petani dengan lahan yang sempit maupun luas memiliki kesempatan yang sama dalam menggunakan asuransi usahatani padi. Sebagian besar petani pada penelitian ini memiliki luas lahan dalam kategori rendah berkisar 0,26 Ha hingga 0,50 Ha. Petani dengan lahan yang sempit mayoritas juga cepat dalam mengambil keputusan untuk menggunakan Asuransi Usahatani Padi (AUTP) karena mereka memperkirakan risiko usahataninya yang sama terutama kekeringan.

d. Pengaruh Pengalaman Usahatani terhadap Pengambilan Keputusan Petani dalam Penggunaan Asuransi Usahatani Padi (AUTP)

Faktor pengalaman usahatani nilai koefisien regresi sebesar 0,520. Koefisien bernilai positif artinya terjadi hubungan yang positif antara faktor pengalaman usahatani dengan pengambilan keputusan sehingga semakin tinggi nilai faktor pengalaman usahatani maka semakin tinggi pula pengambilan keputusan petani. Hal ini sejalan di kondisi lapang bahwa faktor pengalaman usahatani secara parsial berpengaruh signifikan terhadap pengambilan keputusan 
petani dalam penggunaan Asuransi Usahatani Padi (AUTP) di Kecamatan Selogiri, Kabupaten Wonogiri. Hal tersebut ditunjukkan bahwa nilai sig. atau $p$ value pada faktor pengalaman usahatani $\left(\mathrm{X}_{4}\right)$ sebesar $0,000<0,05$ maka Ho diterima dan $\mathrm{H}_{1}$ ditolak.

Pengalaman usahatani berpengaruh nyata terhadap keputusan petani, hal itu sesuai dengan pendapat (Harahap et al., 2018) bahwa pengalaman usaha tani menjadikan petani memiliki keterampilan relatif tinggi dan pertimbangan yang akan dilakukan untuk keberlangsungan usaha taninya. Ratarata responden memiliki pengalaman usaha tani dalam kategori sangat tinggi dengan kurun waktu lebih dari 20 tahun. Petani responden sudah mengetahui masa tanam yang rentan terhadap risiko usahatani terutama pada masa tanam padi ketiga. Petani mengakui dengan menggunakan Asuransi Usahatani Padi (AUTP) dapat dijadikan sebagai salah satu alternatif untuk mengatasi kerugian panen dan tambahan modal untuk masa tanam berikutnya. Petani juga memiliki pengalaman yang bertambah dengan melihat petani desa lain dalam satu kelompok tani yang sama dan sudah pernah memperoleh ganti rugi setelah menggunakan AUTP.

\section{e. Pengaruh Tingkat Pengambilan Risiko terhadap \\ Pengambilan Keputusan Petani dalam Penggunaan Asuransi Usahatani Padi (AUTP)}

Faktor tingkat pengambilan risiko memiliki nilai koefisien regresi sebesar 1,030. Koefisien bernilai positif artinya terjadi hubungan yang positif antara faktor tingkat pengambilan risiko dengan pengambilan keputusan sehingga semakin tinggi nilai faktor tingkat pengambilan risiko maka semakin tinggi pula pengambilan keputusan petani. Hal ini sejalan di kondisi lapang bahwa faktor tingkat pengambilan risiko secara parsial berpengaruh signifikan terhadap pengambilan keputusan petani dalam penggunaan Asuransi Usahatani Padi (AUTP) di Kecamatan Selogiri, Kabupaten Wonogiri. Hal tersebut ditunjukkan bahwa nilai sig. atau $p$ value pada faktor tingkat pengambilan risiko $\left(\mathrm{X}_{5}\right)$ sebesar $0,000<0,05$ maka Ho diterima dan $\mathrm{H}_{1}$ ditolak.

Hasil penelitian sesuai dengan (Prasetyo et al, 2019) bahwa tingkat pengambilan risiko mempengaruhi petani memutuskan untuk mengikuti asuransi usahatani padi, karena petani memperkirakan risiko usahatani. Petani responden paling banyak memiliki tingkat risiko dalam kategori cukup tinggi berupa kekeringan dan hama penyakit. Tingkat risiko mempengaruhi pengambilan keputusan petani dalam Asuransi Usahatani Padi (AUTP) karena mereka tetap memperoleh pendapatan saat panen meskipun mengalami gagal panen. Tingkat risiko usahatani yang dihadapi tinggi maka petani akan lebih mempertimbangkan dan mudah untuk mengambil keputusan dalam penggunaan Asuransi Usahatani Padi (AUTP).

f. Pengaruh Tingkat Keaktifan Penyuluh terhadap Pengambilan Keputusan Petani dalam Penggunaan Asuransi Usahatani Padi (AUTP)

Faktor tingkat keaktifan penyuluh memiliki nilai koefisien regresi sebesar 0,440. Koefisien bernilai positif artinya terjadi hubungan yang positif antara faktor tingkat keaktifan penyuluh dengan pengambilan keputusan sehingga semakin tinggi nilai faktor tingkat keaktifan penyuluh maka semakin tinggi pula pengambilan keputusan petani. Hal ini sejalan di kondisi lapang bahwa faktor tingkat keaktifan penyuluh secara parsial berpengaruh signifikan terhadap pengambilan keputusan petani dalam penggunaan Asuransi Usahatani Padi (AUTP) di Kecamatan Selogiri, Kabupaten Wonogiri. Hal tersebut ditunjukkan bahwa nilai sig. atau $p$ value pada faktor tingkat keaktifan penyuluh $\left(\mathrm{X}_{6}\right)$ sebesar $0,000<0,05$ maka Ho diterima dan $\mathrm{H}_{1}$ ditolak.

Keaktifan penyuluh mempengaruhi pengambilan keputusan petani dalam penggunaan Asuransi Usahatani Padi (AUTP), karena penyuluh menjadi fasilitator untuk mengajak petani dalam menggunakan AUTP. Sumber informasi utama petani responden untuk mengenal AUTP berasal dari penyuluh. Frekuensi penyuluh dalam memberikan penyuluhan kepada petani responden sebanyak 4 kali dalam setahun. Penyuluh memiliki kedekatan kepada petani melalui interaksi sehingga lebih mudah mempengaruhi pengambilan keputusan dan terbuka terhadap inovasi baru untuk usahataninya. Menurut(Malta, 2016), petani yang berinteraksi dengan penyuluh akan memperoleh informasi baru terkait kegiatan usahatani dan bertukar informasi dalam mengatasi masalah yang dihadapi dalam berusahatani.

\section{g. Pengaruh Kemudahan Penggunaan terhadap Pengambilan Keputusan Petani dalam Penggunaan Asuransi Usahatani Padi (AUTP)}

Faktor kemudahan penggunaan memiliki nilai koefisien regresi sebesar 0,313. Koefisien bernilai positif artinya terjadi hubungan yang positif antara faktor kemudahan penggunaan dengan pengambilan keputusan sehingga semakin tinggi nilai faktor tingkat kemudahan penggunaan maka semakin tinggi pula pengambilan keputusan petani. Hal ini tidak sejalan di kondisi lapang bahwa faktor kemudahan penggunaan secara parsial tidak berpengaruh signifikan terhadap pengambilan keputusan petani dalam penggunaan Asuransi Usahatani Padi (AUTP) di Kecamatan Selogiri, Kabupaten Wonogiri. Hal tersebut ditunjukkan bahwa nilai sig. atau $p$ value pada faktor kemudahan penggunaan $\left(\mathrm{X}_{7}\right)$ sebesar 0,106 > 0,05 maka Ho diterima dan $\mathrm{H}_{1}$ ditolak. Kemudahan penggunaan tidak mempengaruhi secara signifikan terhadap pengambilan keputusan petani dalam menggunakan Asuransi Usahatani Padi (AUTP), karena petani tidak merasakan kemudahan khususnya pada proses klaim AUTP. Petani belum mengetahui secara spesifik kriteria kerusakan tanaman untuk dapat diajukan klaim meskipun pada ketentuan intensitas kerusakan $\geq 75 \%$ dari luas lahan.

\section{Kesimpulan}

Berdasarkan hasil analisis dan pembahasan menunjukkan bahwa faktor-faktor yang mempengaruhi pengambilan keputusan petani dalam penggunaan Asuransi Usahatani Padi (AUTP) di Kecamatan Selogiri, Kabupaten Wonogiri terdiri dari pendidikan, pendapatan, luas lahan, pengalaman usahatani, tingkat pengambilan risiko, tingkat keaktifan penyuluh, dan kemudahan penggunaan. Pengambilan keputusan petani dalam penggunaan Asuransi Usahatani Padi (AUTP) di Kecamatan Selogiri, Kabupaten Wonogiri termasuk kategori tinggi. Secara simultan bahwa faktor pendidikan, pendapatan, luas lahan, pengalaman usahatani, tingkat pengambilan risiko, tingkat keaktifan 
penyuluh, dan kemudahan penggunaan berpengaruh signifikan terhadap pengambilan keputusan petani dalam penggunaan Asuransi Usahatani Padi (AUTP) di Kecamatan Selogiri, Kabupaten Wonogiri. Secara parsial bahwa faktor pendidikan, pengalaman usahatani, tingkat pengambilan risiko, dan tingkat keaktifan penyuluh berpengaruh signifikan terhadap pengambilan keputusan petani, sedangkan pendapatan, luas lahan, dan kemudahan penggunaan tidak berpengaruh signifikan terhadap pengambilan keputusan petani dalam penggunaan Asuransi Usahatani Padi (AUTP) di Kecamatan Selogiri, Kabupaten Wonogiri.

\section{Ucapan Terima Kasih}

Penulis mengucapkan terimakasih kepada seluruh pihak yang telah membantu dan memberi semangat dalam menyelesaikan penelitian ini.

\section{Daftar Pustaka}

Aprelesia, R., Syahni, R., \& Triana, L,. 2019. Analisis Faktor-Faktor Yang Mempengaruhi Keputusan Petani Menjadi Peserta Asuransi Usahatani Padi (Autp) Di Kecamatan Pauh Kota Padang. JOSETA: Journal of Socio-Economics on Tropical Agriculture, 1(3), 67-74.

Harahap, J., Sriyoto, S., \& Yuliarti, E,. 2018. Faktor-Faktor Yang Mempengaruhi Pengambilan Keputusan Petani Salak Dalam Memilih Saluran Pemasaran. Jurnal AGRISEP, 17(1), 95-106.

Malta,. 2016. Faktor-Faktor Yang Berhubungan Dengan Kemandirian Petani Dalam Pengambilan Keputusan Untuk Keberlanjutan Usahatani (Kasus: Petani Di Desa Sukaharja - Kabupaten Bogor). Jurnal Sosiohumaniora, 18(2), 118-124.

Mustika, M., Fariyanti, A., \& Tinaprilla, N,. 2019. Analisis Sikap Dan Kepuasan Petani Terhadap Atribut Asuransi Usahatani Padi Di Kabupaten Karawang Jawa Barat. Jurnal Forum Agribisnis, 9(2), 200-214.

Prasetyo et al,. 2019. Faktor Sosial Ekonomi Yang Mempengaruhi Keputusan Petani Mengikuti Program Asuransi Usahatani Padi (AUTP). Jurnal AgribiSains, 5(April), 1-8.

Riyanto dan Aglis,. (2020). Metode Riset Penelitian Kuantitatif Penelitian di Bidang Manajemen, Teknik, Pendidikan, dan Eksperimen. CV. Budi Utama, Yogyakarta.

Rustandi, Y. dan I,. 2017. Analisis Pengambilan Keputusan Keikutsertaan Petani pada Program Asuransi Usahatani Padi (AUTP) di Kabupaten Malang. Jurnal Agriekstensia Vol., 16(2), 279-286.

Syakir, B. S. dan F,. 2016. Respon Petani Terhadap Program Pemerintah Mengenai Asuransi Usahatani Padi (AUTP), Prosiding( Seminar Nasional Pembangunan Pertanian Tahun 2016.

Wahyuningsih, T. A., \& Hasan, F,. 2019. Faktor Sosial Ekonomi Yang Mempengaruhi Keputusan Petani Mengikuti Program Asuransi Usahatani Padi (AUTP). Jsep, 12(3), 11-21. 